\title{
A meta-analysis of paleolimnological records reveals the sensitivity of lacustrine carbon burial rates to carbon sources and preservation conditions during the Anthropocene

\author{
JP. Jenny $^{1 *}$, C. Niemann ${ }^{2}$, P. Francus ${ }^{3}$, A. Noren ${ }^{4}$, N. Carvalhais ${ }^{2,5}$ \\ ${ }^{I}$ INRA, UMR CARRTEL, Université Savoie Mont Mont Blanc, Thonon les Bains, France, \\ ${ }^{2}$ Max Planck Institute for Biogeochemistry, Jena, Germany, \\ ${ }^{3}$ Centre Eau Terre Environnement, INRS, G1K9A9 Québec (Qc), Canada and GEOTOP Research Center, Montréal, \\ (Qc), Canada, ${ }^{4}$ National Lacustrine Core Facility (LacCore), Minneapolis, USA \\ ${ }^{5}$ Departamento de Ciências e Engenharia do Ambiente, DCEA, Faculdade de Ciências e Tecnologia, FCT, \\ Universidade Nova de Lisboa, 2829-516 Caparica, Portugal. \\ *e-mail: jean-philippe.jenny@inrae.fr
}

Inland waters are sites of active carbon (C) processing and transport along the land to ocean aquatic continuum (LOAC) that need to be accounted for closing the global $\mathrm{C}$ budget ${ }^{1,2}$. However, monitoring data are lacking and do not extend back as far as few decades, limiting our comprehension of the LOAC C cycle for the last centuries. Lake sediments provide a key archive for assessing $\mathrm{C}$ transport and transformation that occurs in lake catchments. Here, the analysis of large numbers of samples was performed on 420 lakes sediment records of the world to assess $\mathrm{C}$ burial rates and sources during the last 300 years. $\mathrm{C}$ and $\mathrm{N}$ (organic and mineral forms) on discrete samples were analyzed using a Variomax elemental analyzer to assess total $\mathrm{C}$ sequestration by lakes, $\mathrm{C}$ sources, and long-term changes in the contribution of allochtonous vs autochtonous sources to $\mathrm{C}$ transfers in lake-watersheds. Continuous sediment records were generated using core scanners (i.e. micro-XRF) and computed tomography to provide nearannual trends on terrigenous elements, here used as proxies of allochtonous sources (e.g. Al, Ti, $\mathrm{K}, \mathrm{Fe}$ ), and $\mathrm{Mn}: \mathrm{Fe}$ ratio to infer past oxygen conditions ${ }^{3}$. Our results suggest that establishing a morphology-relevant lake typology that better characterises the types and distribution of oxygen conditions and terrigenous supplies across our sites is therefore the first step in providing a more robust evidence base for explaining the spatial-temporal variation in lake $\mathrm{C}$ burial rates.

1. Montgomery, D. R. Soil erosion and agricultural sustainability. Proc. Natl. Acad. Sci. 104, 13268-13272 (2007).

2. Borrelli, P. et al. An assessment of the global impact of 21 st century land use change on soil erosion. Nat. Commun. 8, 2013 (2017).

3. Jenny, J.-P. et al. Contrasted effects of climate change on temperate large lakes oxygen-depletion (Lakes Geneva, Bourget, Annecy). in vol. 1510075 (2013). 